\title{
Use of Biochemically Improved Shrimp Industry Waste in Fry Tilapia (Oreochromis Niloticus, Linnaeus 1758) Diets: Effects on Growth Performance and Carcass Composition
}

\begin{abstract}
Dior DIOP
Institut Universitaire de Pêche et d'Aquaculture (IUPA) Université Cheikh Anta Diop UCAD II bâtiment pédagogique/Rez de chaussée BP 5005 DAKAR
\end{abstract}

Tel: 221-33-864-5981

Jean FALL (Corresponding author)

Institut Universitaire de Pêche et d'Aquaculture (IUPA) Université Cheikh Anta Diop

UCAD II bâtiment pédagogique/Rez de chaussée BP 5005 DAKAR

Tel: 221-77-956-4339Ｅ-mail: kagoshima77@yahoo.com

\section{Mariama SAGNE}

Institut Universitaire de Pêche et d'Aquaculture (IUPA) Université Cheikh Anta Diop, UCAD II bâtiment pédagogique/Rez de chaussée BP 5005 DAKAR,

Tel: 221-33-864-5981

\section{Abdoulaye LOUM}

Institut Universitaire de Pêche et d'Aquaculture (IUPA) Université Cheikh Anta Diop, UCAD II bâtiment pédagogique/Rez de chaussée BP 5005 DAKAR,

Tel: 221-33-864-5981

\section{Diégane NDONG}

Agence Nationale de l'Aquaculture Cité Comico 3 VDN Liberté 6 Extension LOT N1 
Tel: 221-338-698-450

\begin{abstract}
Malick DIOUF
Institut Universitaire de Pêche et d'Aquaculture (IUPA) Université Cheikh Anta Diop, UCAD II bâtiment pédagogique/Rez de chaussée BP 5005 DAKAR,
\end{abstract}

Tel: 221-33-864-5981

\begin{abstract}
Alassane SARR
Institut Universitaire de Pêche et d'Aquaculture (IUPA) Université Cheikh Anta Diop, UCAD II bâtiment pédagogique/Rez de chaussée BP 5005 DAKAR
\end{abstract}

Tel: 221-33-864-5981

\author{
Nicolas AYESSOU \\ Laboratoire d'Analyses et d'Essais/ Ecole Supérieure Polytechnique \\ Université Cheikh Anta Diop BP 5085 Dakar Fann \\ Tel: $+221-825-0894$
}

Omar Thiom THIAW

Institut Universitaire de Pêche et d'Aquaculture (IUPA) Université Cheikh Anta Diop, UCAD II bâtiment pédagogique/Rez de chaussée BP 5005 DAKAR,

Tel: 221-33-864-5981

Received: April 13, 2013 Accepted: April 26, 2013

doi:10.5296/jbls.v4i2.4091 URL: http://dx.doi.org/10.5296/jbls.v4i2.4091

\begin{abstract}
To evaluate the nutritional quality of the shrimp by-products four approximately isonitrogenous (32 $\pm 2 \%$ crude protein) diets containing different types of shrimp waste meal were fed to duplicate groups of ten fry with an initial mean weight $1.43 \pm 0.22 \mathrm{~g} /$ fish for forty two (42) days. Fishes fed with diet D had the highest mean weight gain (MWG) and specific growth rate (SGR) and those fed with the control diet A had the lowest MWG and SGR.
\end{abstract}


There were no noticeable change in food conversion ratio (FCR) of the fishes fed with diets B, $\mathrm{C}$ and $\mathrm{D}$ which are significantly different from the FCR of those that fed with control diet A. The survival of fry tilapia ranged from 70 to $100 \%$, being $70 \%$ for $\mathrm{D}, 80 \%$ for $\mathrm{B}, 90 \%$ for $\mathrm{C}$ and $100 \%$ for A. There were no significant differences in body protein content among the fish fed with diets B, C, D and the initial fish. The lowest body protein was obtained in the fish fed with control diet. The tilapia fed with control diet had the highest body lipid content as compared to the initial fish. However, there were no significant differences in body lipid content among the fish fed test diets B, C and D as compared to the initial fish. The variations in body ash content of initial fish and those fed with test diets were significantly different. The initial fish had the highest body ash content.

Keywords: Tilapia, Oreochromis niloticus, Shrimp waste Meal, Recirculating system

\section{Introduction}

Nile tilapia (Oreochromis niloticus, Linnaeus 1758) is one of the most cultured fish in tropical and subtropical regions in the world. Tilapia production (except Africa) was 2.4 million metric tons in 2008 representing $8 \%$ of the total freshwater and brackish water fish production (FAO, 2010). Tilapia production in Senegal was only 200 metric tons in 2010 (NAA, 2011).

Shrimp world production was 6 million tons in 2006 (FAO, 2009). In Senegal, shrimp production was estimated to be 4657 metric tons (DPM, 2009). The shellfish-processing industry in Senegal generates about 2794.2 metric tons of waste per year. Shrimp waste considered as an important animal protein source (Fanimo et al. 2000) is essentially composed of heads, shells, appendages and tails, which are potential feedstuff due its minerals, pigments, lipid, and flavors contents. Prawn shell waste protein is rich in essential amino acids (Forster 1975; Penaflorida 1989) and the oil extracted from shrimp head contains polyunsaturated fatty acids (PUFA) essential for fish and shellfish (Joseph \& Meyers 1975; Joseph \& Williams 1975). The most important waste material in shrimp processing industries is head waste, which represents approximately $35-45 \%$ of the whole shrimp weight (Meyers, 1986). Enhanced nutritional value and digestibility of fermented shrimp head waste by fish was reported by Plascencia-Jatomea et al. (2002) and Nwanna (2003). Synowiecki \& Al-Khateeb (2000) revealed that shrimp head waste contents high chitin (11\%, dry weight basis).

This abundant waste may pose a disposal problem due to the ease of spoilage and contributes to the overall cost of the production. To solve this problem it is important to transform waste into either silage or mill and use this material in the formulation of fish feeds. However, the use of shrimp head meal in the formulation of fish feed is not recommended due to its high fiber and ash contents, which results in the formation of weak pellets (Meyers, 1986) with poor stability in water. According to Fagbenro \& Bello-Olusoji (1997), fiber and ash content could be reduced by transformation of shrimp head waste into silage by the process of fermentation. A similar observation on the reduction of ash and fiber in silage was also made by Fox (1994) using formic acid. Consequently, the pellets made of shrimp head silage possessed better structural stability in water.

Shrimp waste is an excellent source of protein (50-65\%, dry weight basis), nutritive 
components and enzymes (Fanimo et al. 2000 and Heu et al. 2003). Therefore, using of such shrimp wastes has drawn much interest from researchers in recent years. Enzymatic hydrolysis method (Cano-Lopez et al. 1987), trypsin (Synowiecki \& Al-Khateeb 2000) and certain proteolytic enzymes such as alcalase (Mizani et al. 2005 and Guerard et al. 2007) have been used to extract the proteins from shrimp waste. These methods are very expensive in commercial enzymes. There is now a need to develop an efficient and economical method for extracting proteins from shrimp waste. Little is known on the protein quality of this important feedstuff.

The biochemical improvement of shrimp waste in the feed processing plant for fish is of economic and environmental benefits. This provides peptides that are more digestible than proteins (Heu et al. 2003). The generation of peptides anti-oxidative activity leads to improved food preservation by inhibiting the oxidation of nutrients, especially lipids and fatty acids (Zo Randriamahatody, 2011). The small-scale production can be achieved through the establishment of a small unit of less expensive feed manufacture on the farm.

The aim of the present study is to evaluate the nutritional value of the diets with respect to weight gain, survival and carcass composition in a feeding trial with Nile tilapia (Oreochromis niloticus Linnaeus, 1758).

\section{Material and Methods}

\subsection{Culture Conditions}

Male sex-reversed tilapia fry (Oreochromis niloticus) of initial weight $1.43 \pm 0.22 \mathrm{~g}$ were collected from the tilapia hatchery in Richard Toll, Saint Louis, Senegal. Fish were acclimated to the experimental conditions for a period of two weeks. During this period, they were fed with a commercial diet as previously occurred at the above mentioned hatchery. To determine the initial body composition, 20 selected fish on a random basis were collected, filleted and stored at $-18^{\circ} \mathrm{C}$ for proximate analysis according to the AOAC (1984). At the beginning of the experiment, 100 tilapia fry were randomly divided into five different groups with two replicates containing 10 fish/each. Fish were kept in 10 glass tank $(50$ x 40 x $30 \mathrm{~cm})$ containers $(50 \mathrm{~L})$. Each aquarium was put in a re-circulating system maintained at $30 \pm 1^{\circ} \mathrm{C}$. An air stone continuously aerated each of both aquariums. All aquaria were cleaned up every day in the morning and the afternoon by siphoning off accumulated waste materials. Fish were then fed with $10 \%$ of body weight per day and gradually decreased to $4 \%$ per day. Each diet was fed twice a day at 08:00 (a.m.) and 17:00 (p.m.) for 42 days to duplicate groups of fish. On the other hand, each group of fish was weighed at the beginning and every two weeks and the amount of diet fed was adjusted, accordingly. A photoperiod of $12 \mathrm{~h}$ light, $12 \mathrm{~h}$ dark (08:00-20:00h) was used, while fluorescent ceiling lights supplied the illumination. After 6 weeks of feeding, fish were taken out from each treatment; the dorsal muscle tissue of each was dissected and used for carcass composition analysis purposes.

\subsection{Raw Materials}

Shrimp (Farfantepenaeus notialis) were caught in the southern Casamance in Senegal and brought to the processing company of fishery products IKAGEL located at Mballing in the 
department of Mbour, Senegal. Once landed, shrimp were checked to confirm their quality level. After processing, heads, shells, tails and appendages are generated. These wastes were kindly donated for our study. The wastes were frozen and transported to the IUPA (Institut Universitaire de Pêche et d'Aquaculture) laboratory.

\subsection{Preparation of shrimp meal}

At the laboratory, the shrimp by-products underwent different treatments namely cooking, steam and silage. Shrimp by-products were divided into 3 batches of $5 \mathrm{~kg}$ each after thawing.

In the first batch, shrimp byproducts were cooked in water at $100{ }^{\circ} \mathrm{C}$ for 20 minutes. After centrifugation, the supernatant was drained and the solid part was dried under the sunlight for 3 days before grinding and sieving.

The second batch was treated according to Cavalheiro et al. 2007. Briefly, shrimp by-product were mixed with $17 \%$ acetic acid and stirred at regular intervals of $2 \mathrm{~h}$ for $24 \mathrm{~h}$ at room temperature $\left(30 \pm 1^{\circ} \mathrm{C}\right)$ to accelerate the liquefaction process by the enzymes naturally present. After this period, the silage thus obtained was dried with forced air circulation for 3 days and then ground before being sieved to obtain flour.

The third batch was treated according to Mirzah, 1997 with some modifications. In fact, shrimp byproducts were steamed using a steamer for 30 minutes. After this operation, the steamed shrimp product was dried under sunlight for 2 days and then ground and sieved.

The different flours obtained were analyzed biochemically according to the standard method AOAC (1984) to know their protein levels.

\subsection{Diet Preparation}

Four diets were formulated to contain $32 \pm 2 \%$ digestible proteins. Main protein sources were fishmeal: $57.7 \%$ crude protein, cooked shrimp byproduct: $48.12 \%$ crude protein, Shrimp byproduct silage: $45.5 \%$ crude protein, steamed shrimp byproduct: $39.38 \%$ crude protein and maize meal: $10.8 \%$ crude protein. There were grounded into mill and passed as particles through $\mathrm{n}^{\mathrm{o}} .40(425 \mu \mathrm{m})$ mesh sieve. Mineral and vitamin premix were purchased from Aquavet feed Company, Thiès, Senegal. After all, ingredients were thoroughly mixed, and appropriate quantity of water provided (30\% for $100 \mathrm{~g}$ of mixed ingredients). Diets were supplemented with $6 \%$ of mixture of fish oil (FO) and vegetable oil (VO) (Table 1).

Table 1. Composition of experimental diets for tilapia (Oreochromis niloticus)

\begin{tabular}{|c|c|c|c|c|}
\hline Ingredients & A & B & $\mathrm{C}$ & $\mathrm{D}$ \\
\hline Fishmeal & 340 & 170 & 170 & 170 \\
\hline Maize meal & 480 & 300 & 280 & 200 \\
\hline Shrimp waste meal & 0 & 350 & 370 & 450 \\
\hline Cellulose & 100 & 100 & 100 & 100 \\
\hline Fish oil & 20 & 20 & 20 & 20 \\
\hline Vegetable oil $(\mathrm{PO}+\mathrm{SO})$ & 40 & 40 & 40 & 40 \\
\hline Vit mix ${ }^{\mathrm{a}}$ & 10 & 10 & 10 & 10 \\
\hline Min $\operatorname{mix}^{\mathrm{b}}$ & 10 & 10 & 10 & 10 \\
\hline
\end{tabular}


$\mathbf{P O}=$ Peanut Oil

$\mathbf{S O}=$ Soybean Oil

a = vit A 250000 UI; vit D3 250000UI; vit E 5000mg; vit B1 100mg; vit B2 400mg ; vit B3(pp) $1000 \mathrm{mg}$; vit B5 pantode Ca2000mg ; vit B6 300mg ; vit K3 1000g ; vit C 5000mg ; H biotin $15 \mathrm{mg}$; choline $100 \mathrm{~g}$; anti-oxydant (BHT), crushed and calcined attapulgite qs $1000 \mathrm{mg} ;$

${ }^{b}=$ phosphorus $7 \%$; calcium $17 \%$; sodium $1,5 \%$; potassium $4,6 \%$; magnesium $7,5 \%$; manganese $738 \mathrm{mg}$; zinc $3000 \mathrm{mg}$; iron $4000 \mathrm{mg}$; copper $750 \mathrm{mg}$; iodine $5 \mathrm{mg}$; cobalt $208 \mathrm{mg}$; calcined and ground attapulgite qs 1000g; fluorine 1.5\% (approximately).

Dough was passed through an extruder to produce spaghetti and dried at $37^{\circ} \mathrm{C}$ for two days. So, the concerned dried diet was packaged into plastic bag and stored frozen until its usage. The experimental diets and samples of the dorsal muscle were analyzed for proximate composition based on AOAC (1984) methods. Crude protein was determined with a Kjeltec system 1002 (Tecator). Crude lipid was determined by chloroform-methanol $(2: 1, \mathrm{v} / \mathrm{v})$ extraction method (Folch et al.1957). Crude fiber was determined by the Fibertec system M 1020 hot extractor (FOSS Tecator). Ash and moisture were determined by conventional methods using muffle furnace at $505^{\circ} \mathrm{C}$ and an oven at $105^{\circ} \mathrm{C}$.

\subsection{Growth Parameters}

Growth response parameters were calculated as follows: Weight gain $(\%)=100 *$ ( (final mean body weight - initial mean body weight)/ initial mean body weight); Specific Growth Rate $(\mathrm{SGR}, \% /$ day $)=100 *((\mathrm{In} \mathrm{Wt}-\mathrm{In} \mathrm{Wi}) / \mathrm{T})$, where Wt is the weight of fish at time t, Wi is the weight of fish at time 0 and $\mathrm{T}$ is the rearing period in days; Feed Conversion Rate $(\mathrm{FCR})=$ total dry feed fed g/ fish / total wet weight gain g/ fish. Survival rate $(\%)=100^{*}$ (number of fish which survived/initial number of fish).

\subsection{Water Quality Measurement}

Water temperature and dissolved oxygen were measured each following day using YSI Model 58 oxygen meter (Yellow Springs Instrument, Yellow Springs, OH, USA).

\subsection{Statistical Analysis}

Data were analyzed using the following statistic system (SAS-PC) (Joyner, 1985) and subjected to one-way analysis of variance (ANOVA). Treatment effects were considered significant at $\mathrm{P}<0.05$; Duncan's test was used to compare significant difference among treatments.

\section{Results}

\subsection{Water Quality Control}

Water quality parameters monitored were similar in all treatments and the values (Temperature $\left.30 \pm 1^{\circ} \mathrm{C}\right)$ and dissolved oxygen $(6 \pm 1 \mathrm{mg} / \mathrm{L})$.

\subsection{Comparison of the Diet Composition}




\section{Ml Macrothink}

The proximate composition of the diets are marginally $(\mathrm{P}>0.05)$ different. Crude protein levels of the diets varied from 30.00 to 34.46 and the lipid content from 7.66 to 11.23, while crude fiber ranged between 2.54 and 8.99 and. Ash of the diets varied from 15.28 to 22.72. There was no significant difference $(\mathrm{P}>0.05)$ in dry matter of the various diets (Table 2$)$.

Table 2. Proximate analysis of experimental diets fed tilapia (Oreochromis.niloticus)

\begin{tabular}{|l|c|c|c|c|}
\hline \multicolumn{5}{|c|}{ Treatments } \\
\hline Composition & A & B & C & D \\
\hline Dry matter* & & & & \\
\hline Crude fiber* & 96 & 95 & 94 & 95 \\
\hline Crude lipid* & 3 & 6 & 7 & 9 \\
\hline Crude protein* & 9 & 10 & 11 & 8 \\
\hline Ash* & 30 & 32 & 33 & 34 \\
Calculated Energy (cal/kg) & 15 & 21 & 18 & 23 \\
\hline
\end{tabular}

* Presented in percentage of dry weight.

\subsection{Comparison of the Growth Parameters}

Fishes fed with diet D had the highest mean weight gain (MWG) and specific growth rate (SGR) which did not vary significantly $(\mathrm{P}>0.05)$ from the MWG and SGR of fishes fed with diets B and $\mathrm{C}$ but differed remarkably $(\mathrm{P}<0.05)$ from the MWG and SGR of fishes fed with control $\operatorname{diet} \mathrm{A}$. However, there were no noticeable change $(\mathrm{P}>0.05)$ in food conversion ratio $(\mathrm{FCR})$ of the fishes fed with diets B, C and D which are significantly different from the FCR of those that fed with control diet A. The survival of fry tilapia ranged from 70 to $100 \%$, being $70 \%$ for $\mathrm{D}$, $80 \%$ for B, $90 \%$ for $\mathrm{C}$ and $100 \%$ for A (Table 3).

Table 3. Initial and final mean weight, mean weight gain, SGR, FCR and survival of Tilapia (Oreochromis niloticus)

\begin{tabular}{|c|c|c|c|c|}
\hline \multicolumn{5}{|c|}{ Treatments } \\
\hline & A & B & C & D \\
\hline Initial mean weight g/ fish & $1.26 \pm 0.00$ & $1.23 \pm 0.01$ & $1.26 \pm 0.03$ & $1.26 \pm 0.01$ \\
\hline Final mean weight g/fish & $3.31 \pm 0.51$ & $4.95 \pm 0.63$ & $5.44 \pm 0.44$ & $6.22 \pm 0.45$ \\
\hline Mean weight Gain g/fish & $2.05 \pm 0.52$ & $3.72 \pm 0.63$ & $4.18 \pm 0.47$ & $4.96 \pm 0.47$ \\
\hline Mean weight Gain (\%) & $163.47 \pm 41.95^{\mathrm{b}}$ & $303.94 \pm 48.40^{\mathrm{ab}}$ & $331.85 \pm 44.34^{\mathrm{ab}}$ & $393.88 \pm 41.35^{\mathrm{a}}$ \\
\hline SGR & $2.29 \pm 0.38^{\mathrm{b}}$ & $3.31 \pm 0.29^{\mathrm{ab}}$ & $3.48 \pm 0.24^{\mathrm{a}}$ & $3.79 \pm 0.20^{\mathrm{a}}$ \\
\hline FCR & $3.35^{\mathrm{b}}$ & $2.17^{\mathrm{a}}$ & $2.18^{\mathrm{a}}$ & $1.69^{\mathrm{a}}$ \\
\hline Survival & 100 & 80 & 90 & 70 \\
\hline
\end{tabular}

${ }^{a b}$ Means in the same column with the different letter are significantly different $(\mathrm{P}<0.05)$. 


\subsection{Comparison of the Carcass Composition}

Table 4 displays the initial and final body compositions of whole fish. There were no significant differences $(\mathrm{P}>0.05)$ in body protein content among the fish fed with diets $\mathrm{B}$, $\mathrm{C}, \mathrm{D}$ and the initial fish. The lowest body protein was obtained in the fish fed with control diet without shrimp waste meal. The tilapia fed with control diet had the highest body lipid content $(\mathrm{P}<0.05)$ compared to the body lipid content of the initial fish. There were no significant differences $(\mathrm{P}>0.05)$ in body lipid content among the fish fed diet with $\mathrm{B}, \mathrm{C}$ and $\mathrm{D}$ compared to the body lipid content of the initial fish. The variations in body ash content of initial fish and those fed with test diets were significantly different. The initial fish had the highest body ash content. However there were no differences $(\mathrm{P}>0.05)$ in body ash content among treatments.

Table 4. Proximate analysis of dorsal muscle of tilapia (Oreochromis niloticus)

\begin{tabular}{|l|c|c|c|c|c|}
\hline \multicolumn{7}{|c|}{ Treatments } \\
\hline Composition & Initial Fish & $\mathrm{A}$ & $\mathrm{B}$ & $\mathrm{C}$ & $\mathrm{D}$ \\
\hline Protein (\%) & 83.77 & 77.63 & 86.43 & 87.00 & 85.93 \\
\hline Lipid (\%) & 8.82 & 10.98 & 9.16 & 9.07 & 9.06 \\
\hline Ash (\%) & 10.10 & 8.27 & 8.02 & 7.91 & 8.52 \\
\hline
\end{tabular}

\section{Discussion}

Water quality parameters monitored were similar in all treatments and the values (Temperature $\left.30 \pm 1{ }^{\circ} \mathrm{C}\right)$ and dissolved oxygen $(6 \pm 1 \mathrm{mg} / \mathrm{L})$, conform to the recommendation of Boyd (1982) for warm water fish culture.

The uses of animal protein sources from fishery by-catch and byproducts for aquaculture have been widely studied by many researchers (Goddard et al. 2003, Li et al. 2004. Goddard \& Perret 2005; Whiteman \& Gatlin III 2005).

The present study showed that the incorporation of shrimp waste product in tilapia diets gave better growth performance compared to the control diet. SGR (3.79) obtained in fish fed on diet D which contains $45 \%$ of shrimp waste product are higher than 2.28 and 1.81 SGR reported respectively by Fagbenro \& Jauncey (1995) and Nwanna 2003. However, the results obtained in this trial are in line with those of Özogul Yesim (1999) who found that the incorporation of proteins of shrimp waste gave the best SGR in the rainbow trout.

Better Leal et al. (2009) demonstrated that the incorporation of protein hydrolysate of shrimp at $60 \%$ did not affect the growth performance of tilapia (O. niloticus). Furthermore, Tibbets et al. (2011) found that the best performance was obtained with the $100 \%$ of krill meal in cod as in the halibut Atlantic. In contrast, Fall et al. (2012) found that the incorporation of shrimp waste meal to replace soybean meal at a concentration greater than $60 \%$ decreased growth performance of hybrid tilapia. Chitmanat et al. (2008) showed that the inclusion of fishery by-product meal more than $25 \%$ was detrimental to growth performance of tilapia. The results of this experiment showed that the steamed shrimp waste product could be included up to $45 \%$ in the diet of tilapia. Cavalheiro et al. (2007) showed that shrimp head silage could substitute 
for fish meal in tilapia fish feed without affecting the nutritional quality of the feed and, at the same time, being economical. The inclusion rate of the present study is higher than that of Mirzah (1997) who included steamed shrimp product in the diet of chickens only up to $18 \%$. However it should be aware that the difference in incorporation rate also depends on the species to be cultured.

In this experiment, the diet $\mathrm{D}$ which gave the best growth performance contains the highest fiber (8.99\%). These fibers are mainly constituted of chitin (30\% to $40 \%$ of the shrimp shell) and chitosan. These results are in contradiction with the observations of Shiau \& Yu (1999), Fall et al. (2012) and Leal et al. (2009). According to these authors, the decrease in growth performance observed from high inclusion level of shrimp waste meal could be explained by poor digestion of chitin. In fact, chitin is known to absorb fat and bile in the gastrointestinal tract, thereby reducing the digestion and absorption of lipids (Tharanathan \& Kittur 2003). It seems that cichlids in general do not have enzymes called chitinases able to digest chitin (Fines \& Holt 2010). In this study, the growth performance recorded may be related to different treatments performed on shrimp waste meal but also the rate of incorporation into diets. In fact, it is known that cooking either steam or boiled transforms the fibers making them more soluble and digestible. Better fiber and ash of a food can be reduced by the process of fermentation (silage) as demonstrated by Fagbenro \& Bello-Olusoji (1997).

The present trial revealed that FCR obtained from fish fed with diets B, C and D did not show any significant differences. The best FCR (1.69) obtained from fish fed with diet D is slightly similar to those obtained by Tibbets et al. 2011. These authors found that the FCR of cod and halibut juveniles fed on diet containing krill meal was around 1.1. In the present experiment, the FCR of fish fed on the different tests diets showed significant variation as compared to that of tilapia fed on the control diet. Contrary, Nwanna (2003) reported that there was no significant difference between FCR of fish fed on the control diet containing no shrimp head silage and other diets containing different inclusion rate of shrimp head hydrolysate in Nile tilapia.

It is known that the survival and growth of fish are closely related to the quality of the feed distributed and, in particular, the protein source (Cruz-Suárez et al. 1992; Cahu \& Zambonino-Infante, 2001). In our study, regardless of the feed distributed, survival rate is relatively high and ranged from 70 to $100 \%$. Similarly, Cavalheiro et al. 2007 revealed that the survival of tilapia varied from $73.0 \%$ to $100 \%$. Moreover, Nwanna, (2003) found survival rates of $95 \%$ during the feeding trials and digestibility studies conducted to evaluate the effect of replacing fish meal by shrimp head meal silage at different levels of $0,5,10,20,30$ and 40\% in the diet of African catfish. According Sumi et al. (2011), a survival rate above $80 \%$ is excellent in nursery.

Biochemical analysis (protein, fat and ash) of the carcass composition of tilapia at the beginning and the end of the experiment are used to determine the influence of diet on the composition of the fish. In the present study, there were no significant differences in body protein content among the fish fed diet with diets B, C, D and the initial fish. The lowest body protein was obtained in the fish fed with control diet without shrimp waste 
meal. The tilapia fed with control diet had the highest body lipid content compared to the body lipid content of the initial fish. There were no significant differences in body lipid content among the fish fed with diets B, C and D compared to the body lipid content of the initial fish. The variations in body ash content of initial fish and fish fed with test diets were significantly different. The initial fish had the highest body ash content. However there were no differences in body ash content among treatments. Nwanna (2003) made similar observation in catfish fed shrimp head silage meal. Contrary to our results, Leal et al. (2009) reported that the carcass protein, ash and fat content of initial fish decreased compared to the carcass composition of fish fed with different diets containing $0,5,10$ and $20 \%$ of shrimp protein hydrolysate in the Nile tilapia.

\section{Conclusion}

Water quality parameters monitored were similar in all treatments and the values (Temperature $\left.30 \pm 1^{\circ} \mathrm{C}\right)$ and dissolved oxygen $(6 \pm 1 \mathrm{mg} / \mathrm{L})$. The proximate composition of the diets is marginally different. The evaluation of nutritional quality of the different shrimp waste meal showed significant difference among treatments in terms of MWG, SGR and survival. The FCR did not demonstrate noticeable change in fishes fed test diets. Chemical analysis of the carcass of the fry tilapia fed the diets containing diverse shrimp waste meal for 42 days differs statistically in terms of protein and lipid content. The results of this study show that shrimp waste meal are important feedstuff for tilapia and steamed shrimp waste meal can be included in tilapia diets up to $45 \%$.

\section{Acknowledge}

We would like to express our thanks to the National Agency of Aquaculture (NAA) for the supply of fish, vitamin and mineral premix. We would highly appreciate the assistance of staff members of ESP (Ecole Supérieure Polytechnique) and ENSA (Ecole Nationale des Sciences Agronomiques) laboratories.

\section{Reference}

AOAC (Association of Official Analysis Chemists). (1984). Official Methods of Analysis, 14th edition, AOAC Arlington, VA, 1141pp.

Boyd, C. E. (1982). Water Quality Management for pond Fish Culture. Elsevier Scientific, Amsterdam. 318p. http://trove.nla.gov.au/version/45493971.

Cahu, C. L., \& Zambonino-Infante, J. L. (2001). Substitution of live food by formulated diet in marine fish larvae. Aquaculture. 200,161-180.

Cano-Lopez, A., Simpson, B. K., \& Haard, N. F. (1987). Extraction of carotenoprotein from shrimp process wastes with the aid of trypsin from Atlantic cod. Journal of Food Science. 52 (2), 503-504. http://dx.doi.org /10.1111/j.1365-2621.1987.tb06656.x

Cavalheiro, J. M. O., Souza, E. O., \& Bora P. S. (2007). Utilization of shrimp industry waste in the formulation of tilapia (Oreochromis niloticus L.) feed. Bioresource. Technology. 98(3), 602-606. http://dx.doi.org/10.1016/j.biortech.2006.02.018, 
Chitmanat, C., Tipin, A., Chaibu, P., Songklanakarin, S. T. (2009). Effects of replacing fishmeal with wastes derived from local fisheries on the growth of juvenile tilapia, Oreochromis niloticus, Songklanakarin Journal of Science and Technology. 31(1), 105-110.

Cruz-Suarez, L. E., Maria, D. M., Vega, J. A. M., \& Ebelling, P. W. (1993). Evaluation of two shrimp by product meals as protein sources in diets for Penaeus vannemei. Aquaculture. 53, 115-116.

DPM. (2009). Resultats généraux des pêches maritimes, Rap-2009, 82pp.

Fagbenro, O.A., \& Jauncey, K. (1995). Growth and Protein Utilization by Juvenile Catfish (Clarias gariepinus) Fed Dry Diets Containing Co- Dried Lactic Acid - Fermented Fish Silage and Protein Feed stuffs. Bioresource Technology. 51, 29-35. http://dx.doi.org/10.1016/0960-8524(94)00064-8.

Fagbenro, O. A., K. Jauncey, \& R. Krueger, 1997. Nutritive Value of Dried Lactic Acid Fermented Fish Silage and Soybean Meal in Dry Diets for Juvenile Catfish, Clarias gariepinus (Burchell, 1822). Journal of Applied. Ichthyology. 13 (1), 27-30. http://dx.doi.org/ 10.1111/j.1439-0426.1997.tb00094.x

Fall, J., Tseng, Y. T., Ndong, D., \& Sheen, S. S. (2012). The effects of replacement of soybean meal by shrimp shell meal on the growth of hybrid tilapia (Oreochromis niloticus $x$ Oreochromis aureus) reared under brackish water. International Journal of Fisheries and Aquaculture. 4(5), 85 - 91. http://dx.doi.org/10.5897/IJFA11.028

Fanimo, A. O., Oduguwa, O. O., Onifade, A. O., Olutunde, T. O. (2000). Protein quality of shrimp-waste meal. Bioresource Technology. 72 (2), 185-188. http://dx.doi.org/10.1016/S0960-8524(99)00108-X

FAO. (2010). Situation mondiale des pêches et de l'aquaculture. Département des pêches et de l'aquculture de la FAO - Organisation des Nations Unies pour l'Alimentation et l'Agriculture. Rome, 2010, 244p.

FAOSTAT. (2009). FAO Statistical Databases, Food and Agricultural Organisation of the United Nations.

Fines, B.C., \& Holt, G. J. (2010). Chitinase and apparent digestibility of chitin in the digestive tract of juvenile cobia, Rachycentron canadum. Aquaculture. 303 (1-4), 34-39. http://dx.doi.org/10.1016/j.aquaculture.2010.03.010

Forster, J. R. M. (1975). Studies on the development of compounded diets for prawns. In: Proceedings of the First International Conference on Aquaculture Nutrition (Price, K.S., Jr, Shaw, W.N. \& Danberg, K.S. eds), pp. 229-248. Delaware Sea Grant College Program and US/Japan Aquaculture Panel, College of Marine Studies, University of Delaware, Newark, NJ, USA.

Fox, C. J., Blow P., Brown J. H., Watson, I. (1994). The effect of various processing methods on the physical and biochemical properties of shrimp head meals and their utilization by juvenile Penaeus monodon Fab. Aquaculture. 122 (2-3), 209-226. 
http://dx.doi.org/10.1016/0044-8486(94)90511-8

Goddard, J. S., McLean, E., \& Wille, K. (2003). Co-dried sardine silage as an ingredient in tilapia, Oreochromis aureus, diets. Journal of Aquaculture in the Tropics. 18, 257-264.

Goddard, J. S., Perret, J. S. M. (2005). Co-drying fish silage for use in aquafeeds. Animal Feed Science and Technology. $118 \quad$ 337-342. http://dx.doi.org/10.1016/j.anifeedsci.2004.11.004.

Guerard, F., Sumaya-Martinez, M. T., Laroque, D., Chabeaud, A., \& Dufosse, L. (2007). Optimization of free radical scavenging activity by response surface methodology in the hydrolysis of shrimp processing discards. Process Biochemistry. 42(11), 1486-1491. http://dx.doi.org/10.1016/j.procbio.2007.07.016.

Heu, M. S., Kim, J.-S., \& ShahidiI, F. (2003). Components and nutritional quality of shrimp

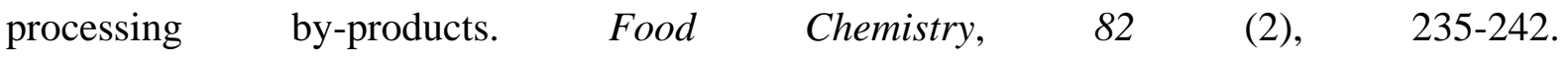
http://dx.doi.org/10.1016/S0308-8146(02)00519-8,

Joseph, J. D. \& Meyers, S. P. (1975). Lipid fatty acid composition of shrimp meals and crustacean diets. Feedstuffs. 47, 35-39.

Joseph, J. D. \& Williams, J. E. (1975). Shrimp head oil: a potential feed additive for mariculture. Proc. Symp. World Maricult. Soc. 6, 147-152.

Joyner S. P. (1985). SAS/STAT Guide for Personal Computer, Statistical Analysis System Institute, Cary, NC, USA.

Leal, A. L. G., De Castro, P. F., De Lima, J. P. V., De Souza Correia, E., De Souza Bezerra, R. (2010). Use of shrimp protein hydrolysate in Nile tilapia (Oreochromis niloticus, L.) feeds, Aquaculture International.18 (4), 635-646. http://dx.doi.org/10.1007/s10499-009-9284-0.

Li, P., Wang, X., Hardy, R. W., Gatlin, D. M. III. (2004). Nutritional value of fisheries by-cacth and by-product meals in the diet of red drum (Sciaenops ocellatus). Aquaculture. 236(1-4), 485-496. http://dx.doi.org/10.1016/j.aquaculture.2004.02.010,

Mizani, M., Aminlari, M., \& Khodabandeh, M. (2005). An effective method for producing a nutritive protein extract powder from shrimp-head waste. Food Science and Technology International. 11(1), 49-54 http://dx.doi.org/10.1177/1082013205051271.

Meyers, S. P. (1986). Utilization of Shrimp Processing Wastes. Infofish Marketing Dig. 4/86, 18-19.

Mirzah. (1997). The Influence of shrimp waste meal processing with steam pressure at quality and its utilization in broiler ration. Dissertation, Padjadjaran University, Bandung.

Nwanna, L. C. (2003). Nutritional Value and Digestibility of Fermented Shrimp Head Waste Meal by African Catfish Clarias gariepinus. Pakistan Journal of Nutrition. 2 (6), 339-345.

Özogul, Y. (2000). The Possibility of Using Crustacean Waste Products (CWP) on Rainbow Trout (Oncorhynchus mykiss) Feeding. Turkish Journal of Biology. 24, 845-854. 
Penaflorida, V. D. (1989). An evaluation of indigenous protein sources as potential component in the diet formulation for the tiger prawn Penaeus monodon using essential amino acid index. Aquaculture. 83(3-4), 319-330. http://dx.doi.org/10.1016/0044-8486(89)90043-4.

Plascencia-Jatomea, M., Olvera-Novoa, M. A., Arredondo-Figueroa, J. L., Hal, G.M., \& Shirai, K. (2002). Feasibility of fishmeal replacement by shrimp head silage protein hydrolysate in Nile tilapia (Oreochromis niloticus L) diets. Journal of the Science of Food and Agriculture. 82 (7), 753-759. http://dx.doi.org/10.1002/jsfa.1092.I

Shiau, S. Y., \& Yu, Y. P. (1999). Dietary supplementation of chitin and chitosan depresses growth in tilapia, Oreochromis niloticus $x$ O. aureus. Aquaculture. 179(1-4), 439-446. http://dx.doi.org/10.1016/S0044-8486(99)00177-5.

Sklan, D., Prag, T., \& Lupatsch, I. (2004). Structure and function of the small intestine of the tilapia Oreochromis niloticus X Oreochromis aureus (Teleostei, Cichlidae). Aquaculture Reseach. 35(4), 350-357. http://dx.doi.org/10.1111/j.1365-2109.2004.01020.x

Sumi, K. R., Das, M., \& Siddika, I. (2011). Effect of different protein levels of fry feed on the production of quality tilapia (Oreochromis niloticus) fry. Journal Bangladesh Agriculture. 9(2), 365-374. http://dx.doi.org/10.3329/jbau.v9i2.11053.

Synowiecki \& Al-Khateeb. (2000). The recovery of protein hydrolysates during enzymatic isolation of chitin from shrimp Crangon crangon processing discards. Food Chemistry. 68 (2), 147-152. http://dx.doi.org/10.1016/S0308-8146(99)00165-X.

Tharanathan, R. N. \& Kittur, F. S. (2003). Chitin -The undisputed biomolecule of great potential. Critical Reviews in Food Science and Nutrition. 43 (1), 61-87. http://dx.doi.org 10.1080/10408690390826455

Tibbets, S. M., Olsen, R. E., Lall, S. P. (2011). Effects of partial of total replacement of fish meal with freeze- dried krill (Euphasia superba) on growth and nutrient utilization of juvenile Atlantic cod (Gadus morhua) and Atlantic halibut (Hippoglossus hippoglossus) feed the same practical diets. Aquaculture nutrition. 17(3), 287-303. http://dx.doi.org 10.1111/j.1365-2095.2010.00753.x.

Whiteman, K. W., Gatlin, D. M. III. (2005). Evaluation of fisheries by-catch and by-product meals in diets for red drum Sciaenops ocellatus L. Aquaculture Research. 36 (16),1572-1580. http://dx.doi.org 10.1111/j.1365-2109.2005.01380.x

\section{Copyright Disclaimer}

Copyright reserved by the author(s).

This article is an open-access article distributed under the terms and conditions of the Creative Commons Attribution license (http://creativecommons.org/licenses/by/3.0/). 